\title{
NOCTP and NRCT Are Not Complete without Tailored Motivational Communication
}

\author{
René Joseph Maria Gruythuysen ${ }^{\mathrm{a}}$ Cor van Loveren ${ }^{\mathrm{b}}$ \\ Rob Cornelis Wilhelmus Burgersdijk ${ }^{c}$ \\ a Dental Office, Tandzorg.nl, Rotterdam, The Netherlands; ${ }^{\text {b}}$ Department of Preventive Dentistry, Academic Centre for \\ Dentistry Amsterdam (ACTA), Amsterdam, The Netherlands; 'Pediatric Dentistry, Department of Preventive and Restorative \\ Dentistry, Radboud Institute for Health Sciences, Radboud University Medical Center, Nijmegen, The Netherlands
}

\section{Dear Editor,}

We understand why the article entitled "Terminology of Dental Caries and Dental Caries Management: Consensus Report of a Workshop Organized by ORCA and Cariology Research Group of IADR" [Machiulskiene et al., 2020] was written. It seeks to give clarity and help readers re-evaluate their thoughts on caries management and control. It should be noted several co-authors had already agreed on (slightly) different definitions of some of the concepts in a consensus paper 4 years ago [Innes et al., 2016]. The discussion section of the present article does not discuss these differences. There are other unexplained deviations from known definitions such as ultraconservative caries treatment (UCT) where two very different definitions can be found in the literature [MertzFairhurst et al., 1998; Mijan et al., 2014] of which just one was chosen. This may confuse colleagues. However, our main concern is the lack of priority given to self-care as an effective management tool and recognition that guiding self-care is the main non-operative/non-restorative tool for dental professionals. The emphasis on guiding self-care guidance is particularly missed in the definitions for "non-operative caries treatment/management/control/care" (NOCTP) and "non-restorative/non-operative cavity treatment" (NRCT). We use the word "guiding" because non-operative treatment should do more than transfer knowledge; it should also generate patients' (and professionals') confidence in the value of self-care and their ability to perform it adequately.

We think that the description of non-operative caries treatment (NOCTP) "key elements can include brushing with fluoride toothpaste, other fluoride treatments, dietary modification, oral hygiene measures, etc." is confirming the traditional approach of overloading patients with information. This approach has not been successful for many of them. The effect of NOCTP has been shown (in spite of variances in quality of the performed communication) in numerous studies [Ekstrand and Christiansen, 2005; Ekstrand et al., 2000; Vermaire et al., 2014] and presented many times at ORCA congresses. The key elements of the success were to strive for tailoring of messages, recall visits based on caries risk and creating confidence in self-care using motivational communication. Unfortunately, none of these key elements is included in the definition.

Equally unfortunately, there is no reference to self-care in the definition of NRCT. The method was originally described in 2010 by Gruythuysen [2010, 2019] as a 5-step protocol: (1) written informed consent; (2) making the cav- karger@karger.com www.karger.com/cre

(C) 2021 S. Karger AG, Base

Karger"
René Gruythuysen

Dental Office, Tandzorg.n

Mathenesserlaan $192^{\mathrm{a}}$

NL-3014 HE Rotterdam (The Netherlands)

r.gruyt@planet.nl 
ity accessible for plaque removal; (3) treating carious dentine with anticariogenic agents and/or applying a protective layer to the carious dentine; (4) monitoring the caries process; (5) effective communication about dental health education. As yet, no prospective clinical study has followed the original 5-step NRCT concept. After over 10 years of experience with NRCT, a paper was published stressing the benefits of this aetiological treatment as first option, refuting prejudgements and explaining the crucial role of motivational communication [Gruythuysen, 2019]. It was also pointed out that poor home oral health care for a child may be a sign of child neglect. Therefore, in the same paper it was recommended that general and oral health providers should work together to prevent the risk of neglect.

Ironically only the operative step "removal of overhanging enamel margins" (an operative step that is not always needed) entered the definition of non-restorative/ non-operative cavity treatment. The definition given does not corroborate with the supporting literature either [Hansen and Nyvad, 2017; Santamaria et al., 2017] where the dentine was protected by professional fluoride applications and by the explicit instruction to brush the cavity. Unfortunately, even these two studies are not clear about their strategy to involve the patients in self-care. The selfcare aspect of NRCT did probably not get sufficient attention but got bogged down in the traditional way of overloading patients with information rather than use the patients' own resources.

The definitions in the paper [Machiulskiene et al., 2020] seem to combine care, management and control, but these may be quite distinct actions in terms of what/ who is targeted (lesion or patient), who is the performer (professional or patient) and what is the goal: lesion re- pair (treatment of symptoms) or healthy oral environment (aetiological approach). There is no distinction between the symptomatic approach and the aetiological approach. For example, UCT was only included as a description at lesion level wherein caries was covered by a restoration as part of a symptomatic approach (the Mertz-Fairhurst definition) and not as was shown in the successful study regarding the mainly non-restorative treatment at child level and as aetiological therapy (the Mijan definition, 2014). By not clarifying this, the authors increase the risk that colleagues will select the most convenient, most profitable, most secure way, continuing to blame the patient for not listening rather than investing in proper behavioural change techniques.

When we do not take the challenge to define or describe the state of the art of effective health education in the dental office, the results of our efforts will be disappointing and not help the patients who will otherwise be paralysed by the amount of information conveyed. Furthermore, we are withholding effective treatment from children.

\section{Conflict of Interest Statement}

The first author reports personal fees (lectures, articles and [online] courses about aetiological caries management). There are no restrictions regarding the submission for publication. The co-authors have no conflicts of interest to declare.

\section{Author Contributions}

The letter is an initiative of the first author and the result of a discussion between the authors.

\section{References}

Ekstrand KR, Christiansen ME. Outcomes of a non-operative caries treatment programme for children and adolescents. Caries Res. 2005 Nov-Dec;39(6):455-67.

Ekstrand KR, Kuzmina IN, Kuzmina E, Christiansen ME. Two and a half-year outcome of caries-preventive programs offered to groups of children in the Solntsevsky district of Moscow. Caries Res. 2000 Jan-Feb;34(1):8-19.

Gruythuysen RJ. Niet-restauratieve caviteitsbehandeling. Cariësactiviteit beteugelen in plaats van maskeren. Ned Tijdschr Tandheelkd. 2010 Mar;117(3):173-80.

Gruythuysen RJ. Non-restorative cavity treatment: should this be the treatment of choice? Reflections of a teacher in Paediatric Dentistry. Dent Update. 2019;46(3):220-8.
Hansen NV, Nyvad B. Non-operative control of cavitated approximal caries lesions in primary molars: a prospective evaluation of cases. J Oral Rehabil. 2017 Jul;44(7):537-44.

Innes NP, Frencken JE, Bjørndal L, Maltz M, Manton DJ, Ricketts D, et al. Managing Carious Lesions: Consensus Recommendations on Terminology. Adv Dent Res. 2016 May;28(2):49-57.

Machiulskiene V, Campus G, Carvalho JC, Dige I, Ekstrand KR, Jablonski-Momeni A, et al. Terminology of Dental Caries and Dental Caries Management: Consensus Report of a Workshop Organized by ORCA and Cariology Research Group of IADR. Caries Res. 2020;54(1):7-14.

Mertz-Fairhurst EJ, Curtis JW Jr, Ergle JW, Rueggeberg FA, Adair SM. Ultraconservative and cariostatic sealed restorations: results at year 10 . Am Dent Assoc. 1998 Jan;129(1):55-66.
Mijan M, de Amorim RG, Leal SC, Mulder J, Oliveira L, Creugers NH, et al. The 3.5-year survival rates of primary molars treated according to three treatment protocols: a controlled clinical trial. Clin Oral Investig. 2014 May;18(4):1061-9.

Santamaría RM, Innes NP, Machiulskiene V, Schmoeckel J, Alkilzy M, Splieth CH. Alternative Caries Management Options for Primary Molars: 2.5-Year Outcomes of a Randomised Clinical Trial. Caries Res. 2018 Jan;51(6):60514.

Vermaire JH, Poorterman JH, van Herwijnen L, van Loveren C. A three-year randomized controlled trial in 6-year-old children on cariespreventive strategies in a general dental practice in the Netherlands. Caries Res. 2014; 48(6):524-33. 